\title{
Steam reforming of methanolfor hydrogen production over nano-structured wire-like molybdenum carbide catalyst
}

\author{
Yufei Ma ${ }^{a}$, Guoqing Guan ${ }^{a, b}$, Patchiya Phanthong ${ }^{a}$, Xiumin $^{a}{ }^{a}, \mathrm{Ji} \mathrm{Cao}^{a}$, \\ Xiaogang $\mathrm{Hao}^{c}$, Zhongde $\mathrm{Wang}^{c}$, Abuliti Abudula ${ }^{a, b *}$ \\ ${ }^{a}$ Graduate School of Science and Technology, Hirosaki University, 3 Bunkyo-cho, \\ Hirosaki, Aomori 036-8561, Japan \\ ${ }^{b}$ North Japan Research Institute for Sustainable Energy, Hirosaki University, 2-1-3 \\ Matsubara, Aomori 030-0813, Japan \\ ${ }^{c}$ Department of Chemical Engineering, Taiyuan University of Technology, Taiyuan \\ 030024, China
}

Corresponding authors: Tel.: +81-17-762-7756; fax:+81-17-735-5411.

E-mails: guan@cc.hirosaki-u.ac.jp (G.Guan); abuliti@cc.hirosaki-u.ac.jp(A. Abudula)

1

(C) 2014. This manuscript version is made available under the Elsevier user license http://www.elsevier.com/open-access/userlicense/1.0/ 


\begin{abstract}
Steam reforming of methanol over nanostructured wire-like molybdenum carbides, which weresynthesizedby direct carburization of aniline-intercalated molybdenum based organic-inorganic hybrid composite at different temperatures, were investigated in details.SEM and TEM images revealed that the obtained wire-like molybdenum carbide wascomposed of nano-particles (10-20 nm) and had microporous structure. These wire-like molybdenum carbides showed higher catalytic activity than those synthesized via the conventional temperature programmed reduction (TPRe) method. It is foundthat the wire-like molybdenum carbide synthesized at $675^{\circ} \mathrm{C}$ had higher surface area $\left(93.2 \mathrm{~m}^{2} / \mathrm{g}\right)$ and showed more excellent catalytic activity and longer term stability.XRD results indicated that more $\alpha-\mathrm{MoC}_{1-\mathrm{x}}$ phase existed in this kind of molybdenum carbide. It indicated that an alternative high-performancemolybdenum carbide catalyst can be easily obtained by adjusting the synthesis condition.
\end{abstract}

Keywords:Methanol; Hydrogen; Molybdenum carbide; Wire-like morphology; Organic-inorganic hybrid material; Catalytic activity; Long-term stability. 


\section{Introduction}

Production of hydrogen via the steam reforming of methanol is considered as one of best ways for providing hydrogen for fuel cell in the future since liquid methanol with high energy density has no $\mathrm{C}-\mathrm{C}$ bond, sulfur free, and is easily handled[1-3].Steam reforming of methanol could be realized effectively at relatively low temperature in the presence of catalyst [4-6].In the developing catalysts, molybdenum carbide is one of the possibly applicable catalysts[7-11].Molybdenum carbide itself can be used directly for the steam reforming of methanol[12].In order to promote its catalytic activity and improve its stability, it was loaded on other supports [13-15] or doped by some metals such as $\mathrm{Pt}, \mathrm{Ni}, \mathrm{Co}$, Feand $\mathrm{Cu}[16-19]$. In our previous studies $[16,17,19], \mathrm{Pt}, \mathrm{Ni}$ and $\mathrm{Cu}$ were doped on molybdenum carbide by carburization of metal doped molybdenumoxide via the temperature-programmed reduction (TPRe) method for the steam reforming of methanol.Due to the strong metal-support interaction between the doped metal and molybdenum carbide support, Pt doped molybdenum carbide exhibited highcatalyticactivity and 100\% methanol conversion was reached at a reaction temperature as low as $200{ }^{\circ} \mathrm{C}$ while Ni doped molybdenum carbide showed a long-term stability and the methanol conversion kept at about $90 \%$ for $50 \mathrm{~h}$ at $300{ }^{\circ} \mathrm{C}$. XPS analysis indicated that the deactivation of molybdenum carbide in SRM reaction is due to the surface oxidation $[16,17,19]$.

TraditionalTPRe method for the preparation of molybdenum carbide has some disadvantages: (i) the flammable mixture of hydrogen and carbon-containing gases 
including $\mathrm{CH}_{4}, \mathrm{C}_{2} \mathrm{H}_{6}, \mathrm{C}_{3} \mathrm{H}_{8}$ and $\mathrm{C}_{4} \mathrm{H}_{10}$ [20-22]are employed; (ii) complex and strict synthesis conditions such as the precise control of temperature heating rate $\left(1{ }^{\circ} \mathrm{C} / \mathrm{min}\right)$ and exact gas compositions and flow rates are necessary; (iii) large-scale productionis impossible.Especially, molybdenum carbide produced from the TPRe methodisalways covered by the polymeric carbon species resulting from the carbon-containing gases so that some active sites are lost, reducing the catalytic activity. In general, the surface area of the obtained molybdenum carbideby this method is much low. Thus, new strategies for the synthesis of nano-structured molybdenum carbide are highly desired.

Recently, an effective and convenient route for the preparation of nanostructured molybdenum carbide via carburization of organic-inorganic hybrid amine-containingmolybdenum based materials was proposed [23].Using this route, it is possible to prepare a large amount of tunable nano-structured molybdenum carbide with high surface areaand enriched porosity. It is found that the obtained molybdenum carbidecatalystswith nanowiremorphology hada good performance for the production of hydrogen from methanol decomposition [24]. In the present study, the same nanostructured wire-like molybdenum carbideswere synthesized at different carburization temperatures and applied for the steam reforming of methanol at different temperatures. The effect of the carburization temperature on thecatalytic performance and the long-term stability were evaluated and discussed in details.Physicochemical propertiesof the catalysts before and after the reaction were characterized by XRD,FT-IR, BET, TEM, SEM and EDS. 


\section{Experimental}

\subsection{Catalystpreparation}

Nanostructured wire-like molybdenum carbides were prepared by following the method reportedin the literature [24] with a minor modification. Firstly, $\mathrm{MoO}_{\mathrm{x}}$ /aniline hybrid precursors $\left(\mathrm{Mo}_{3} \mathrm{O}_{10}\left(\mathrm{C}_{6} \mathrm{H}_{5} \mathrm{NH}_{3}\right)_{2} \cdot 2 \mathrm{H}_{2} \mathrm{O}\right)$ was prepared as follows:2.48 $\mathrm{g}$ of ammonium heptamolybdate $\left(\left(\mathrm{NH}_{4}\right)_{6} \mathrm{Mo}_{7} \mathrm{O}_{24} \cdot 4 \mathrm{H}_{2} \mathrm{O}\right.$, Konjundo Chem Lab, Japan $)$ was dissolved in $40 \mathrm{ml}$ of distilled water, followed by addition of $3.34 \mathrm{~g}$ aniline in it; then, $1 \mathrm{M} \mathrm{HCl}$ was added dropwise in the above solution with stirring at room temperature until the precipitate appeared; and then it was heated at $50{ }^{\circ} \mathrm{C}$ under stirring for 2.5 hours; the final product was filtrated, washed with ethanol and water until $\mathrm{pH}$ value $=7$, anddried at $50{ }^{\circ} \mathrm{C}$ in air overnight.

Carburization ofthe obtained $\mathrm{MoO}_{\mathrm{x}}$ /anilineprecursor wascarried out in afixed-bed quartz micro-reactor with an inner diameter of $10 \mathrm{~mm}$.Firstly, air in the reactor was purged out by $\operatorname{Ar}\left(10 \mathrm{~cm}^{3} / \mathrm{min}\right)$ at room temperature for $4 \mathrm{~h}$, and then heated to final carburization temperature (i.e., 675,725 and $750{ }^{\circ} \mathrm{C}$, respectively, in this study) with a ramping rate of $2{ }^{\circ} \mathrm{C} / \mathrm{min}$ in $\mathrm{Ar}$ flow gas anda flow rate of 50 $\mathrm{cm}^{3} / \mathrm{min}$, and remainedat the final temperature for $5 \mathrm{~h}$. As-obtained catalyst was cooled down to RT in theAr flow and finally passivatedin $1 \% \mathrm{O}_{2} / \mathrm{Ar}$ for $12 \mathrm{~h}$ at room temperature.The as-prepared catalyst is denoted as wire- $\mathrm{Mo}_{\mathrm{x}} \mathrm{C}_{\mathrm{y}}-\mathrm{CT}$, where $\mathrm{CT}$ is calcination temperature $\left(675,725\right.$ and $\left.750{ }^{\circ} \mathrm{C}\right)$. For comparison, molybdenum carbide sample was also prepared using the TPRe method as reportedin our previous studies $[16,17,19]$.The as-prepared catalyst is denoted as TPRe-Mo $\mathrm{Mo}_{2} \mathrm{C}$ 


\subsection{Catalystcharacterization}

Crystallinestructure of the catalyst before and after the reaction was determined by X-ray diffraction (XRD 610, Shimadzu, Japan). The radiation used was $\mathrm{CuK} \alpha$ and the operating potential was $30 \mathrm{kVwith}$ a current of $30 \mathrm{~mA}$ and a scanning rate $4 \%$ min. BET (Brunauer-Emmett-Teller) surface area was measured through nitrogen adsorption at liquid-nitrogen temperature $(77 \mathrm{~K})$ using a Quantachrome NOVA 4200esurface area andpore size analyzer.The IR spectra were analyzed using FT-IR (JASCO 4200, USA).The microstructure and morphology were characterized witha scanning electron microscope (SEM, S-8000, Hitachi, Japan). Transmission electron microscope (TEM) images were obtained using a JEM-2100F transmission electron microscope JEOL operating at $200 \mathrm{kV}$.

\subsection{Catalytic performance evaluation}

Catalytic performance of as-preparedmolybdenum carbidefor the steam reforming of methanol(SRM) reactionwas evaluated in a micro-reactor with an inner diameter of $6 \mathrm{~mm}$. Priorto the reaction, the catalyst was pretreated with $15 \% \mathrm{CH}_{4} / \mathrm{H}_{2}$ at $590^{\circ} \mathrm{C}$ for $2 \mathrm{~h}$ in order to reduce the surface oxide. The pretreated condition was chosen based on our preliminary experiments, which are not shown here. The total amount of the catalyst used was $0.4 \mathrm{~g}$, anda weight hourly space velocity (WHSV) of $9000 \mathrm{~cm}^{3} \mathrm{~g}^{-1} \mathrm{~h}^{-1}$ was selected in this study. Methanol and water mixture with a molar ratio of $1: 1\left(13 \% \mathrm{CH}_{3} \mathrm{OH}-13 \% \mathrm{H}_{2} \mathrm{O}\right.$ in $\left.\mathrm{Ar}\right)$ was injected into the reactor with a 
syringe pump.It was vaporized in a pre-heater containing $\mathrm{ZrO}_{2}$ beads and carried by Ar gas flow. Catalytic performance was tested at different temperatures from $200-400$ ${ }^{\circ} \mathrm{C}$ and at atmospheric pressure.For comparison, the sampling was carried out after 1 hour reaction at each temperature. For stability test, the time-on-streamsamplinganalysis was performed every 1 hourduring the reaction at $400{ }^{\circ} \mathrm{C}$. Herein, a thermocouple was inserted in the catalytic bed for the reaction temperature control. A water-ice cold trap was set at the exit of the reactor to condense the unconvertedmethanol and steam. The products were analyzed using a gas chromatograph with TCD detector (Agilent 7890A GC system) and a gas chromatograph with FID detector (Shimadzu GC-2014). The outlet gas flow rate was determined by inner standard method, in which the flow rates of $\mathrm{CH}_{4}, \mathrm{CO}$, and $\mathrm{CO}_{2}$ were calculated based on the flow rate of inner gas $\mathrm{N}_{2}$ in the reaction system while that of $\mathrm{H}_{2}$ was calculated based on the flow rate of inner gas $\mathrm{He}$ in the reaction system.

Performances of the catalysts were characterized in terms of methanol conversion. The methanol conversion was defined as the molar ratio of the gaseous carbon compounds $\left(\mathrm{CH}_{4}, \mathrm{CO}\right.$, and $\left.\mathrm{CO}_{2}\right)$ in the product stream to the feed methanol since only traces of other products such as $\mathrm{C}_{2} \mathrm{H}_{6}, \mathrm{C}_{2} \mathrm{H}_{4}$ and $\mathrm{HCOOH}$ in outlet gas and liquid were detected in this study. Methanol conversionwas defined as:

$$
\mathrm{X}_{\mathrm{CH}_{3} \mathrm{OH}}=\frac{\mathrm{n}_{\mathrm{CO}}+\mathrm{n}_{\mathrm{CO}_{2}}+\mathrm{n}_{\mathrm{CH}_{4}}}{\mathrm{n}_{\mathrm{CH}_{3} \mathrm{OH}}} \times 100 \%
$$

wheren $\mathrm{CO}_{\mathrm{CO}}, \mathrm{n}_{\mathrm{CH} 4}$, and $\mathrm{n}_{\mathrm{CH} 3 \mathrm{OH}}$ are the flow rates of $\mathrm{CO}, \mathrm{CO}_{2}, \mathrm{CH}_{4}$ in the outlet products and methanol in the feed, respectively. The molar fraction of a product 
component was defined as the molar ratio of this specific product to the total gaseous product.

\section{Results and discussion}

\subsection{Physicochemical properties}

Morphology, chemical composition and crystal structure of $\mathrm{Mo}_{3} \mathrm{O}_{10}\left(\mathrm{C}_{6} \mathrm{H}_{5} \mathrm{NH}_{3}\right)_{2} \cdot 2 \mathrm{H}_{2} \mathrm{O}$ synthesized by aniline organic precursors are shown in Fig.

1. One can see that molybdate-aniline precursor showed uniformly wire-like morphology(Fig. 1 (a)) with a length of about $23 \mu \mathrm{m}$ and a width of about 100-250 nm. EDS analysis( Fig.1 (b)) indicated that the molybdate-aniline precursor consisted of Mo, C, $\mathrm{N}$ and $\mathrm{O}$ elements, but the signal of $\mathrm{N}$ element was weak. It might be due to that the concentration of $\mathrm{N}$ element in compounds is ultralow based on the chemical formula of $\mathrm{Mo}_{3} \mathrm{O}_{10}\left(\mathrm{C}_{6} \mathrm{H}_{5} \mathrm{NH}_{3}\right)_{2} \cdot 2 \mathrm{H}_{2} \mathrm{O}$, in which the $\mathrm{N}$ element weight concentration is $4 \%$. Furthermore, it is generally difficult to detect the light element such as $\mathrm{N}$ using EDS.Therefore, the chemical compositions werefurtherconfirmed by FT-IR. As shown inFig. 1 (c), the bands at 3026 and $2918 \mathrm{~cm}^{-1}$ are attributed to the stretching vibration of $\mathrm{C}-\mathrm{H}$ in benzene ring; the adsorption at $2584 \mathrm{~cm}^{-1}$ is ascribed to the stretching vibration of $-\mathrm{NH}^{3+}$; the bands at $1115 \mathrm{~cm}^{-1}$ is contributed to the stretching vibration of $\mathrm{C}-\mathrm{N}$; the bands at 1581 and $1494 \mathrm{~cm}^{-1}$ should be assigned to the vibration of the benzene ring; and the bands at 948 and $889 \mathrm{~cm}^{-1}$ should be contributed to the stretching vibration of $\mathrm{Mo}=\mathrm{O}$ and $\mathrm{Mo}-\mathrm{O}$, respectively. These FT-IR results confirmed that molybdate-aniline precursor contained aniline and molybdenum oxide. All peaks in the XRD pattern(Fig.1(d)) were in agreement with the characteristic diffraction 
peaks of $\mathrm{Mo}_{3} \mathrm{O}_{10}\left(\mathrm{C}_{6} \mathrm{H}_{5} \mathrm{NH}_{3}\right)_{2} \cdot 2 \mathrm{H}_{2} \mathrm{O}$.

Fig. 2 shows XRD patterns of the as-prepared freshTPRe-Mo $2 \mathrm{C}$, wire- $\mathrm{Mo}_{\mathrm{x}} \mathrm{C}$ $\mathrm{y}^{-\mathrm{CT}}\left(\mathrm{CT}=675,725\right.$ and $\left.750{ }^{\circ} \mathrm{C}\right)$, and wire- $-\mathrm{Mo}_{\mathrm{x}} \mathrm{C}_{\mathrm{y}}-675^{\circ} \mathrm{Cafter}$ pretreatment under $\mathrm{CH}_{4} / \mathrm{H}_{2}$ at $590{ }^{\circ} \mathrm{C}$. Herein, the peaks at $2 \theta$ of $34.8^{\circ}, 38.4^{\circ}$ and $39.8^{\circ}$ are attributed to the presence of hexagonal $\beta-\mathrm{Mo}_{2} \mathrm{C}$ phase with hcp crystal structure while the peaks at $2 \theta$ of $37.1^{\circ}$ and $42.8^{\circ}$ are attributed to cubic $\alpha-M_{1-x}$ phase with fcc crystal structure. For the fresh wire- $\mathrm{Mo}_{\mathrm{x}} \mathrm{C}_{\mathrm{y}}-675^{\circ} \mathrm{C}$, the peak at $25.9^{\circ}$ is attributed to molybdenum oxide $\left(\mathrm{MoO}_{2}\right)$. It should be noted that there are no peaks related to the metal molybdenumfor all the as-prepared catalysts. These results indicated that the carbon and nitrogen atom in the organic precursor could reduce and carburize the molybdenum oxide. One can see that the fresh wire-like molybdenum carbides had two phases, i.e., $\alpha$ and $\beta$ phases. With the increase in the carburization temperature, the peak intensity of the $\beta$ phase was increased while thatof the $\alpha$ phase was decreased, indicating that at higher temperature, the thermodynamicallymetastable $\alpha$ phase is easily transferred to the stable $\beta$ phase. In general, thermodynamically metastable $\alpha-\mathrm{MoC}_{1-\mathrm{x}}$ is synthesized by nitrogenization of $\mathrm{MoO}_{3}$ under ammonia atmospherefor theformation of $\mathrm{Mo}_{2} \mathrm{~N}$ at first and subsequently converting to $\alpha-\mathrm{MoC}_{1-\mathrm{x}}$ under the mixture of hydrogen and carbon containing gas during carburizationprocess [25, 26].Therefore, in thepresent case, it can be speculated that $\mathrm{N}$ atom in aniline could nitrogenizeand reduce molybdenum oxide to $\mathrm{Mo}_{2} \mathrm{~N}$ at first, and then $\mathrm{Mo}_{2} \mathrm{~N}$ is carburized by $\mathrm{C}$ atom to $\alpha-\mathrm{MoC}_{1-\mathrm{x}}$. On the other hand, based onFig.2, for the fresh wire- $\mathrm{Mo}_{\mathrm{x}} \mathrm{C}_{\mathrm{y}}-675^{\circ} \mathrm{C}, \mathrm{MoO}_{2}$ existed. However, when the carburizationtemperature was 
increased over $725^{\circ} \mathrm{C}$, pure molybdenum carbide pattern appeared. It is possible that the carburization temperature is too low to efficiently carburize all molybdenum oxide to molybdenum carbide at $675{ }^{\circ} \mathrm{C}$. However, after the pretreatment under $\mathrm{CH}_{4} / \mathrm{H}_{2}$ at $590{ }^{\circ} \mathrm{C}, \mathrm{MoO}_{2}$ phase disappeared, indicating that the remained $\mathrm{MoO}_{2}$ in the fresh wire- $\mathrm{Mo}_{\mathrm{x}} \mathrm{C}_{\mathrm{y}}-675^{\circ} \mathrm{C}$ was easily carburized under the pretreatment atmosphere. For other samples, the XRD patterns after the pretreatment were almost the same as the fresh ones. The results were not shown here. In contrast, $\mathrm{TPRe}-\mathrm{Mo}_{2} \mathrm{C}$ only containedthe stable $\beta$ phase.

SEM images of $\beta-\mathrm{Mo}_{2} \mathrm{C}$ synthesized by the TPRe method and the wire- $\mathrm{Mo}_{\mathrm{x}} \mathrm{C}-$

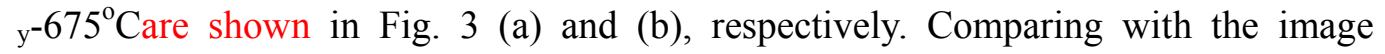
shown in Fig.1(a),the wire- $\mathrm{Mo}_{\mathrm{x}} \mathrm{C}_{\mathrm{y}}-675^{\circ} \mathrm{Cremained}$ the wire-like morphology (Fig. 3 (b)) as the molybdate-aniline precursor. The wire length was about $8.5 \mu \mathrm{m}$, and the width is about 100-250 $\mathrm{nm}$. Comparing with the organic-inorganic precursor, the width kept at the same, but the length became short. This might be due to the material broken during the carburization process athigh temperature. In contrast, the $\beta-\mathrm{Mo}_{2} \mathrm{C}$ synthesized by thetraditional TPRe method showedrandom large particle morphology (Fig. 3 (a)).

TEM images of $\beta-\mathrm{Mo}_{2} \mathrm{C}$ synthesized by theTPRe method and the wire- $\mathrm{Mo}_{\mathrm{x}} \mathrm{C}$ $\mathrm{y}^{-} 675^{\circ} \mathrm{C}$ are shown in Fig. 3 (c) and (d), respectively. Obviously, the wire-like molybdenum carbide was composed of nano-particles with a size of about 10-20 nm, and these nanoparticleswere connected with each other and thus,the wire-like molybdenum carbide had porous nanostructure, which could provide larger surface 
area and more catalytic active sites. As shown in Table 1, the nano-structured wire-like molybdenum carbide had much higher surface area than that of $\mathrm{Mo}_{2} \mathrm{C}$ synthesized by the traditional TPRe method. However, it should be noted that with the increasein the carburization temperature, the surface area was decreased from 93.2 to $33.01 \mathrm{~m}^{2} / \mathrm{g}$. It is possible thatthe particle sintering could occur at high carburization temperature, resulting in some nano-pore blocked. On the other hand, in general, comparing with $\beta-\mathrm{Mo}_{2} \mathrm{C}, \alpha-\mathrm{MoC}_{1-\mathrm{x}}$ showed higher surface area [27-29]. From the XRD patterns shown in Fig.2, one can see that with the increase in the carburization temperature, the peakintensity of the $\alpha$ phase decreased.

Fig. 4schematically illustrates the synthesis process for the formation of the wire-like molybdenum carbide. Herein, the organic precursor served as the template to drive the molybdenum precursor to the wire-like morphology, and this morphology was maintained until the end of carburization process. It should be noted that the $\mathrm{C}$ and $\mathrm{N}$ atom in organic precursor served as the reducing agent which reduced molybdenum oxide and carburized molybdenum oxide to molybdenum carbide.

\subsection{Catalytic performance}

Catalytic performances of TPRe- $\mathrm{Mo}_{2} \mathrm{C}$ and wire- $\mathrm{Mo}_{\mathrm{x}} \mathrm{C}_{\mathrm{y}}-\mathrm{CT}(\mathrm{CT}=675,725$ and $750{ }^{\circ} \mathrm{C}$ ) catalystsfor the steam reforming of methanolwere evaluated in details in a temperature range of $200-400{ }^{\circ} \mathrm{C}$ with a WHSV of $9000 \mathrm{~cm}^{3} \mathrm{~g}^{-1} \mathrm{~h}^{-1}$ and a steam-to-carbon molar ratio of 1 . The results were expressed as the methanol conversion versus temperature. As shown in Fig. 5, it is found that the catalytic 
performances of the wire- $\mathrm{Mo}_{\mathrm{x}} \mathrm{C}_{\mathrm{y}}-\mathrm{CT}\left(\mathrm{CT}=675,725\right.$ and $\left.750{ }^{\circ} \mathrm{C}\right)$ were higher thanthat of TPRe-Mo $-\mathrm{Mo}_{2} \mathrm{C}$. As indicated in Table 1 and Fig. 3, it is possible that the higher surface area and nano-porous structureof the wire-like molybdenum carbidecould providemore active sites for the steam reforming of methanol. Herein, it should be noted thatthe catalytic activity decreased as the wire-Mo $\mathrm{Mo}_{\mathrm{y}}-\mathrm{CT}$ was prepared at higher carburization temperature and the wire- $\mathrm{Mo}_{\mathrm{x}} \mathrm{C}_{\mathrm{y}}-675{ }^{\circ} \mathrm{C}$ showed the highest methanol conversion at different reforming temperatures: the methanol conversion reached $30 \%$ at $200{ }^{\circ} \mathrm{C}$ and the highest methanol conversion was reached when the reaction temperature was increased to $350{ }^{\circ} \mathrm{C}$. As indicated above, compared with other wire- $\mathrm{Mo}_{\mathrm{x}} \mathrm{C}_{\mathrm{y}}$, the wire- $\mathrm{Mo}_{\mathrm{x}} \mathrm{C}_{\mathrm{y}}-675{ }^{\circ} \mathrm{C}$ hadmuch highersurface area $(93.2 \mathrm{~m} / \mathrm{g})$, which could provide more active sites on the catalyst surface. Furthermore, it is possible that more $\alpha-\mathrm{MoC}_{1-\mathrm{x}}$ existed in the wire- $\mathrm{Mo}_{\mathrm{x}} \mathrm{C}_{\mathrm{y}}-675{ }^{\circ} \mathrm{C}$, which is more active than $\beta-\mathrm{Mo}_{2} \mathrm{C}$ phase for the steam reforming ofmethanol $[16,30]$.

Fig. 6 shows the product compositions over $\mathrm{TPRe}-\mathrm{Mo}_{2} \mathrm{C}$ and wire- $\mathrm{Mo}_{\mathrm{x}} \mathrm{C}-$ $\mathrm{y}^{-\mathrm{CT}}\left(\mathrm{CT}=675,725\right.$ and $\left.750{ }^{\circ} \mathrm{C}\right)$ corresponding to the results shown in Fig. 5. In all cases, $\mathrm{H}_{2}$ and $\mathrm{CO}_{2}$ are the two main products in the outlet gas, together with a small amount of $\mathrm{CO}$ and $\mathrm{CH}_{4}$. In the present study, only traces of other products such as $\mathrm{C}_{2} \mathrm{H}_{6}, \mathrm{C}_{2} \mathrm{H}_{4}$ and $\mathrm{HCOOH}$ were detected for any catalyst. As we known, $\mathrm{CO}$ is a poison gas for fuel cell Pt-based catalysts and has to be removed or converted in a practical reforming process for the application of fuel cells. Herein, for TPRe- $\mathrm{Mo}_{2} \mathrm{C}$,with the increase in the reaction temperature, the $\mathrm{CO}$ percentage increased from 0 to $10 \%$. In contrast, forthe wire- $\mathrm{Mo}_{\mathrm{x}} \mathrm{C}_{\mathrm{y}}-\mathrm{CTs}$, the $\mathrm{CO}$ percentage was 
lower than $5 \%$ when the reaction temperature was in range of 200 to $400{ }^{\circ} \mathrm{C}$. It is possible that the wire- $\mathrm{Mo}_{\mathrm{x}} \mathrm{C}_{\mathrm{y}}-\mathrm{CT}$ sprovided higher surface area and more active sitesfor water gas shift (WGS) reaction $\left(\mathrm{CO}+\mathrm{H}_{2} \mathrm{O} \rightarrow \mathrm{CO}_{2}+\mathrm{H}_{2}\right)$ as well. Several researches reported that WGS reaction could happen in SRM reaction over molybdenumcarbide catalysts $[13,16,17]$.

On the other hand, for all catalysts, one can see that with the increase in the reaction temperature, $\mathrm{H}_{2}$ percentage decreased while $\mathrm{CH}_{4}$ percentage increased to some extent. $\mathrm{CH}_{4}$ is an unwanted by-product for the hydrogen production from SRM. In this study, the concentration of $\mathrm{H}_{2}$ and $\mathrm{CH}_{4}$ can be considered as the result of the competition reactions between the WGS and methanation $\left(\mathrm{CO}+3 \mathrm{H}_{2} \rightarrow \mathrm{CH}_{4}+\mathrm{H}_{2} \mathrm{O}\right)$. One can see that more $\mathrm{H}_{2}$ was obtained if the methanatiom reaction was hindered. Comparing with $\mathrm{TPRe}-\mathrm{Mo}_{2} \mathrm{C}$, the methane concentration was hindered when the wire- $\mathrm{Mo}_{\mathrm{x}} \mathrm{C}_{\mathrm{y}}-675{ }^{\circ} \mathrm{C}$ catalyst was used.

\subsection{Catalytic stability}

Fig.7 shows the catalytic stability test results for $\mathrm{TPRe}-\mathrm{Mo}_{2} \mathrm{C}$ and wire- $\mathrm{Mo}_{\mathrm{x}} \mathrm{C}-$ $\mathrm{y}^{-\mathrm{CT}}\left(\mathrm{CT}=675,725\right.$ and $\left.750{ }^{\circ} \mathrm{C}\right)$ catalysts at $400{ }^{\circ} \mathrm{C}$. One can see that for TPRe- $\mathrm{Mo}_{2} \mathrm{C}$ catalyst, the methanol conversion rate was decreased rapidly from $100 \%$ to $10 \%$ in 9 h. In contrast, the catalytic stability was obviouslyenhanced when the wire- $\mathrm{Mo}_{\mathrm{x}} \mathrm{C}_{\mathrm{y}}$ catalysts were used.With the decrease in the carburation temperature of the preparation of wire- $\mathrm{Mo}_{\mathrm{x}} \mathrm{C}_{\mathrm{y}}$, the catalytic stability performance increased.Especially, forthe wire- $\mathrm{Mo}_{\mathrm{x}} \mathrm{C}_{\mathrm{y}}-675{ }^{\circ} \mathrm{C}$, the methanol conversion kept at about $95 \%$ in $12 \mathrm{~h}$, 
suggesting that it is a very stablecatalyst for the steam reforming of methanol. In contrast, for the wire- $\mathrm{Mo}_{\mathrm{x}} \mathrm{C}_{\mathrm{y}}-725{ }^{\circ} \mathrm{C}$ and wire- $\mathrm{Mo}_{\mathrm{x}} \mathrm{C}_{\mathrm{y}}-750{ }^{\circ} \mathrm{C}$ catalysts, the methanol conversions weredecreased from $100 \%$ to $70 \%$ and $30 \%$ in $12 \mathrm{~h}$, respectively.

Fig. 8 showsthe product compositions during the stability test related to Fig.7. For TPRe- $\mathrm{Mo}_{2} \mathrm{C}$ catalyst, the outlet gas compositions were also unstable: $\mathrm{CO}$ percentage in the outlet gas increased from $5 \%$ to about $20 \%$ while $\mathrm{CO}_{2}$ percentage decreased from about 23 to $10 \%$ after $9 \mathrm{~h}$ reaction, and the $\mathrm{H}_{2}$ percentage also decreased to some extent. In contrast, when wire- $\mathrm{Mo}_{\mathrm{x}} \mathrm{C}_{\mathrm{y}}-\mathrm{CT}$ catalysts were used, the stability of product compositions was enhanced obviously.Especially, over thewire-Mo $\mathrm{Mo}_{\mathrm{y}}-675^{\circ} \mathrm{C}$ (Fig. 8 (d)), the composition stability was very high: the $\mathrm{CO}_{2}$ percentage remained at about $20 \%$ and $\mathrm{CO}$ kept lower than $5 \%$ after $12 \mathrm{~h}$ reaction.

Fig. 9shows the XRD patterns of the spent catalysts after the stability test as indicated in Fig. 7. Herein, nopeaks of $\mathrm{MoO}_{3}$ and other molybdenum oxide appeared in the XRD patterns. In our previous studies [16,17,19], the deactivation of molybdenum carbide was confirmed to bedue to the surface oxidation, but suggested that the oxidized layer should be only a few molecule layers, which is difficult to be detected by XRD. As the molybdenum carbide is in the reduce state, $\mathrm{H}_{2} \mathrm{O}$ molecule could be easily adsorbed and dissociated on it. Moon et al. [21] reported that the deactivation of molybdenum carbide should be due to the $\mathrm{Mo}_{2} \mathrm{C}$ transfer to $\mathrm{MoO}_{3}$ with the reaction of $\mathrm{H}_{2} \mathrm{O}$ in reactant during the WGS reaction. Here, as reported in our previous studies $[16,17,19]$, the deactivation of catalyst should be also due to the oxidization of the molybdenum carbide surface by $\mathrm{H}_{2} \mathrm{O}$. However, it should be noted 
that the stability of the wire- $\mathrm{Mo}_{\mathrm{x}} \mathrm{C}_{\mathrm{y}}$, could be enhanced to some extentdue to the high surface area and more active sites.

\section{Conclusions}

Wire-like molybdenum carbide catalysts were synthesized by carburization of organic-inorganic hybrid materials under inert gas atmosphere at different temperatures, and applied for the steam reforming of methanol reaction at temperatures in the range of $200-400{ }^{\circ} \mathrm{C}$. The following results were obtained:

(a) XRD analysis indicated that the crystal structure of the obtained wire-like molybdenum carbide catalyst depended on the carburization temperature. $\alpha-\mathrm{MoC}_{1-\mathrm{x}}$ phase always appeared at a relatively low temperature, and with the increase in the carburization temperature, $\beta-\mathrm{Mo}_{2} \mathrm{C}$ phase increased.

(b) SEM and TEM images revealed that the obtained wire-like molybdenum carbides were composed of nano-particles (10-20 nm) and had porous structures.

(c) These wire-like molybdenum carbides showed higher catalytic activity than those synthesized via the conventional temperature programmed reduction (TPRe) method. It is found thatthe wire-like molybdenum carbide synthesized at $675^{\circ} \mathrm{C}$ had higher surface area $\left(93.2 \mathrm{~m}^{2} / \mathrm{g}\right)$ and showed more excellent catalytic activity and longer term stability.

\section{Acknowledgements}


This work is supported by Japan Science and Technology Agency (JST), Japan and Aomori City Government. Ma thanks the State Scholarship Fund of China Scholarship Council (2012).P. Phanthonggratefully acknowledges the scholarship from Ministry of Education, Culture, Sport, Science, and Technology (MEXT) of Japan. The authors also thank Dr Yutaka Kasai at Aomori Prefectural Industrial Technology Research Center for their technical support on experiments. 


\section{References}

[1] Zhang XR, Wang LC, Yao CZ, Cao Y, Dai WL, He HY, Fan KN. A highly efficient $\mathrm{Cu} / \mathrm{ZnO} / \mathrm{Al}_{2} \mathrm{O}_{3}$ catalyst via gel-coprecipitation of oxalate precursors for low-temperature steam reforming of methanol.Catal Lett 2005; 102: 183-90.

[2] Wu GS, Mao DS, Lu GZ, Cao Y, Fan KN. The role of the promoters in Cu based catalysts for methanol steam reforming.Catal Lett 2009; 130: 177-84

[3] Sá S, Silva H, Brandão L, Sousa JM. Mendes A. Catalysts for methanol steam reforming-A review.Appl Catal B Environ 2010; 99: 43-57.

[4]Yang L, Lin GD, Zhang HB. Highly efficient Pd-ZnO catalyst doubly promoted by CNTs and $\mathrm{Sc}_{2} \mathrm{O}_{3}$ for methanol steam reforming.Appl Catal A Gen 2013; 455: 137-44.

[5] Men Y, Yang M. SMSI-like behavior and Ni promotion effect on NiZnAl catalysts in steam reforming of methanol.Catal Commun 2012; 22: 68-73.

[6] Segal SR, AndersonKB, CarradoKA, MarshallCL. Low temperature steam reforming of methanol over layered double hydroxide-derived catalysts.Appl Catal A Gen 2002; 231: 215-26.

[7] York AP, Pham-Huu C, Del Gallo P, Blekkan EA, Ledoux MJ. Comparative Effect of Organosulfur Compounds on Catalysts for the n-Heptane Isomerization Reaction at Medium Pressure: $\mathrm{Mo}_{2} \mathrm{C}$-Oxygen-Modified, $\mathrm{MoO}_{3}$-Carbon-Modified, $\mathrm{Pt} / \gamma-\mathrm{Al}_{2} \mathrm{O}_{3}$, and Pt/ $\beta$-Zeolite Catalysts.Ind Eng Chem Res 1996; 35:672-82.

[8] Shi C, Zhang A, Li X, Zhang S, Zhu A, Ma Y, Au C. Ni-modified $\mathrm{Mo}_{2} \mathrm{C}$ catalysts for methane dry reforming. Appl Catal A Gen 2012;431:164-70.

[9] Lee JS, Yeom MH, Park KY, Nam IS, Chung JS, Kim YG. Preparation and 
benzene hydrogenation activity of supported molybdenum carbide catalysts. J Catal 1991;128:126-36.

[10] Brungs AJ, York AP, Claridge JB, Márquez-Alvarez C, Green ML. Dry reforming of methane to synthesis gas over supported molybdenum carbide catalysts.Catal Lett 2000; 70: 117-22.

[11] Blekkan EA, Pham-Huu C, Ledoux MJ, Guille J. Isomerization of n-heptane on an oxygen-modified molybdenum carbide catalyst. Ind Eng Chem Res 1994;33:1657-64.

[12] Széchenyi A, Solymosi F. Production of hydrogen in the decomposition of ethanol and methanol over unsupported $\mathrm{Mo}_{2} \mathrm{C}$ catalysts. J Phys Chem $\mathrm{C}$ 2007;111:9509-15.

[13] Barthos R, Solymosi F. Hydrogen production in the decomposition and steam reforming of methanol on $\mathrm{Mo}_{2} \mathrm{C} /$ carbon catalysts. J Catal 2007;249:289-99.

[14] Koós Á, Barthos R, Solymosi F. Reforming of Methanol on a K-Promoted $\mathrm{Mo}_{2} \mathrm{C} /$ Norit Catalyst. J Phys Chem C 2008;112:2607-12.

[15] Lin SSY, Thomson WJ, Hagensen TJ, Ha SY. Steam reforming of methanol using supported $\mathrm{Mo}_{2} \mathrm{C}$ catalysts. Appl Catal A Gen 2007;318:121-7.

[16] Ma Y, Guan G, Shi C, Zhu A, Hao X, Wang Z, Kusakabe K, Abudula A. Low-temperature steam reforming of methanol to produce hydrogen over various metal-doped molybdenum carbide catalysts.Int J Hydrogen Energy 2014; 39:258-66.

[17] Ma Y, Guan G, Phanthong P, Hao X, Huang W, Tsutsumi A, Kusakabe K, Abudula A. Catalytic Activity and Stability of Nickel Modified Molybdenum Carbide 
Catalysts for Steam Reforming of Methanol.J Phys Chem C 2014; 118:9485-96.

[18] Setthapun W, Bej SK, Thompson LT. Carbide and Nitride Supported Methanol Steam Reforming Catalysts: Parallel Synthesis and High Throughput Screening.Top Catal 2008; 49: 73-80.

[19] Ma Y, Guan G, Hao X, Zuo Z, Huang W, Phanthong P, Kusakabe K, Abudula A. Highly-efficient steam reforming of methanol over copper modified molybdenum carbide. RSC Adv 2014, DOI: 10.1039/C4RA05673F.

[20] Nagai M, Matsuda K. Low-temperature water-gas shift reaction over cobalt-molybdenum carbide catalyst. J Catal 2006;238:489-96.

[21] Moon DJ, Ryu JW. Molybdenum carbide water-gas shift catalyst for fuel cell-powered vehicles applications.Catal Lett 2004; 92: 17-24.

[22] Bastos LC, Monteiro WR, Zacharias MA, da CruzGM, Rodrigues JAJ. Preparation and characterization of $\mathrm{Mo} / \mathrm{W}$ bimetallic carbides by using different synthesis methods.Catal Lett 2008; 120: 48-55.

[23] Gao Q, Wang S, Tang Y, Giordano C. Preparation of organic-inorganic hybrid $\mathrm{Fe}-\mathrm{MoO}_{\mathrm{x}} /$ polyaniline nanorods as efficient catalysts for alkene epoxidation.Chem Commun 2012; 48:260-62.

[24] Gao Q, Zhang C, Xie S, Hua W, Zhang Y, Ren N, Xu H, Tang Y. Synthesis of Nanoporous Molybdenum Carbide Nanowires Based on Organic-Inorganic Hybrid Nanocomposites with Sub-Nanometer Periodic Structures. Chem Mater 2009; 21: $5560-62$.

[25] Lee J, Volpe L, Ribeiro F, Boudart M. Molybdenum carbide catalysts: II. 
Topotactic synthesis of unsupported powders. J Catal 1988;112:44-53.

[26] Jung KT, Kim WB, Rhee CH, Lee JS. Effects of transition metal addition on the solid-state transformation of molybdenum trioxide to molybdenum carbides. Chem Mater 2004;16:307-14.

[27] Kojima R, Aika K. Molybdenum nitride and carbide catalysts for ammonia synthesis. Appl Catal A Gen 2001;219:141-7.

[28] Bouchy C, Schmidt I, Anderson J, Jacobsen C, Derouane E, Derouane-Abd Hamid S. Metastable fcc $\alpha-\mathrm{MoC}_{1-\mathrm{x}}$ supported on HZSM5: preparation and catalytic performance for the non-oxidative conversion of methane to aromatic compounds. J Mol Cataly A Chem 2000; 163:283-96.

[29] Tsuji M, MiyaoT, Naito S. Remarkable support effect of $\mathrm{ZrO}_{2}$ upon the $\mathrm{CO}_{2}$ reforming of $\mathrm{CH}_{4}$ over supported molybdenum carbide catalysts.Catal Lett 2000; 69:195-8.

[30] Ranhotra G, Bell A, Reimer J. Catalysis over molybdenum carbides and nitrides: II. Studies of CO hydrogenation and $\mathrm{C}_{2} \mathrm{H}_{6}$ hydrogenolysis.J Catal 1987; 108:40-9. 


\section{Figure captions}

Fig.1(a) SEM image, (b) EDS pattern, (c) FT-IR spectra and (d) XRD pattern of $\mathrm{MoO}_{\mathrm{x}}$-aniline hybrid precursors.

Fig.2 XRD patterns of TPRe- $\mathrm{Mo}_{2} \mathrm{C}$, fresh wire- $\mathrm{Mo}_{\mathrm{x}} \mathrm{C}_{\mathrm{y}}-\mathrm{CT}\left(\mathrm{CT}=675,725\right.$ and $\left.750{ }^{\circ} \mathrm{C}\right)$ catalysts and wire- $\mathrm{Mo}_{\mathrm{x}} \mathrm{C}_{\mathrm{y}}-675^{\circ} \mathrm{C}$ after pretreatment.

Fig.3 (a) SEM image of TPRe-Mo $2 \mathrm{C}$, (b) SEM image of wire- $\mathrm{Mo}_{\mathrm{x}} \mathrm{C}_{\mathrm{y}}-675^{\circ} \mathrm{Cand}$ (c) TEM image of TPRe- $\mathrm{Mo}_{2} \mathrm{C}$ and (d) TEM image of wire- $\mathrm{Mo}_{\mathrm{x}} \mathrm{C}_{\mathrm{y}}-675^{\circ} \mathrm{C}$.

Fig.4Schematic illustration of the synthesis of wire- $\mathrm{Mo}_{\mathrm{x}} \mathrm{C}_{\mathrm{y}}$ from organic-inorganic hybrid material using aniline as organic precursor.

Fig.5Catalytic activities over TPRe- $\mathrm{Mo}_{2} \mathrm{C}$ and wire-like molybdenum carbides with different carburization temperatures

Fig.6Product compositions over wire-like molybdenum carbide catalyst (a) $\mathrm{TPRe}-\mathrm{Mo}_{2} \mathrm{C}$; (b) wire- $\mathrm{Mo}_{\mathrm{x}} \mathrm{C}_{\mathrm{y}}-750^{\circ} \mathrm{C}$, (c) wire- $\mathrm{Mo}_{\mathrm{x}} \mathrm{C}_{\mathrm{y}} \quad-725^{\circ} \mathrm{Cand} \quad$ (d) wire- $\mathrm{Mo}_{\mathrm{x}} \mathrm{C}_{\mathrm{y}}-675^{\circ} \mathrm{C}$.

Fig.7Time-on-stream testing ofTPRe- $\mathrm{Mo}_{2} \mathrm{C}$ and wire-like molybdenum carbide catalysts at $400{ }^{\circ} \mathrm{C}$.

Fig.8Product compositions for stability test over wire-like molybdenum carbide catalysts(a) $\mathrm{TPRe}-\mathrm{Mo}_{2} \mathrm{C}$; (b) wire- $\mathrm{Mo}_{\mathrm{x}} \mathrm{C}_{\mathrm{y}}-750^{\circ} \mathrm{C}$; (c) wire- $\mathrm{Mo}_{\mathrm{x}} \mathrm{C}_{\mathrm{y}}-725^{\circ} \mathrm{C}$ and (d) wire- $\mathrm{Mo}_{\mathrm{x}} \mathrm{C}_{\mathrm{y}}-675^{\circ} \mathrm{C}$

Fig.9XRD patterns of the spent catalysts after stability tests shown in Fig. 7. 
Table 1 BET surface areas of wire-like molybdenum carbide catalysts.

\begin{tabular}{cccc}
\hline Catalysts & $\boldsymbol{S}_{\mathbf{B E T}}\left(\mathbf{m}^{\mathbf{2}} / \mathbf{g}\right)$ & Catalysts & $\boldsymbol{S}_{\mathbf{B E T}}\left(\mathbf{m}^{\mathbf{2}} / \mathbf{g}\right)$ \\
\hline $\mathrm{Mo}_{2} \mathrm{C}$ & 5.8 & $\mathrm{Mo}_{\mathrm{x}} \mathrm{C}_{\mathrm{y}}\left(725^{\circ} \mathrm{C}\right)^{\mathrm{a}}$ & 37.22 \\
$\mathrm{Mo}_{\mathrm{x}} \mathrm{C}_{\mathrm{y}}\left(675^{\circ} \mathrm{C}\right)^{\mathrm{a}}$ & 93.2 & $\mathrm{Mo}_{\mathrm{x}} \mathrm{C}_{\mathrm{y}}\left(750^{\circ} \mathrm{C}\right)^{\mathrm{a}}$ & 33.01 \\
\hline
\end{tabular}

${ }^{a}$ wire-like molybdenum carbide 


\section{Figure 1}

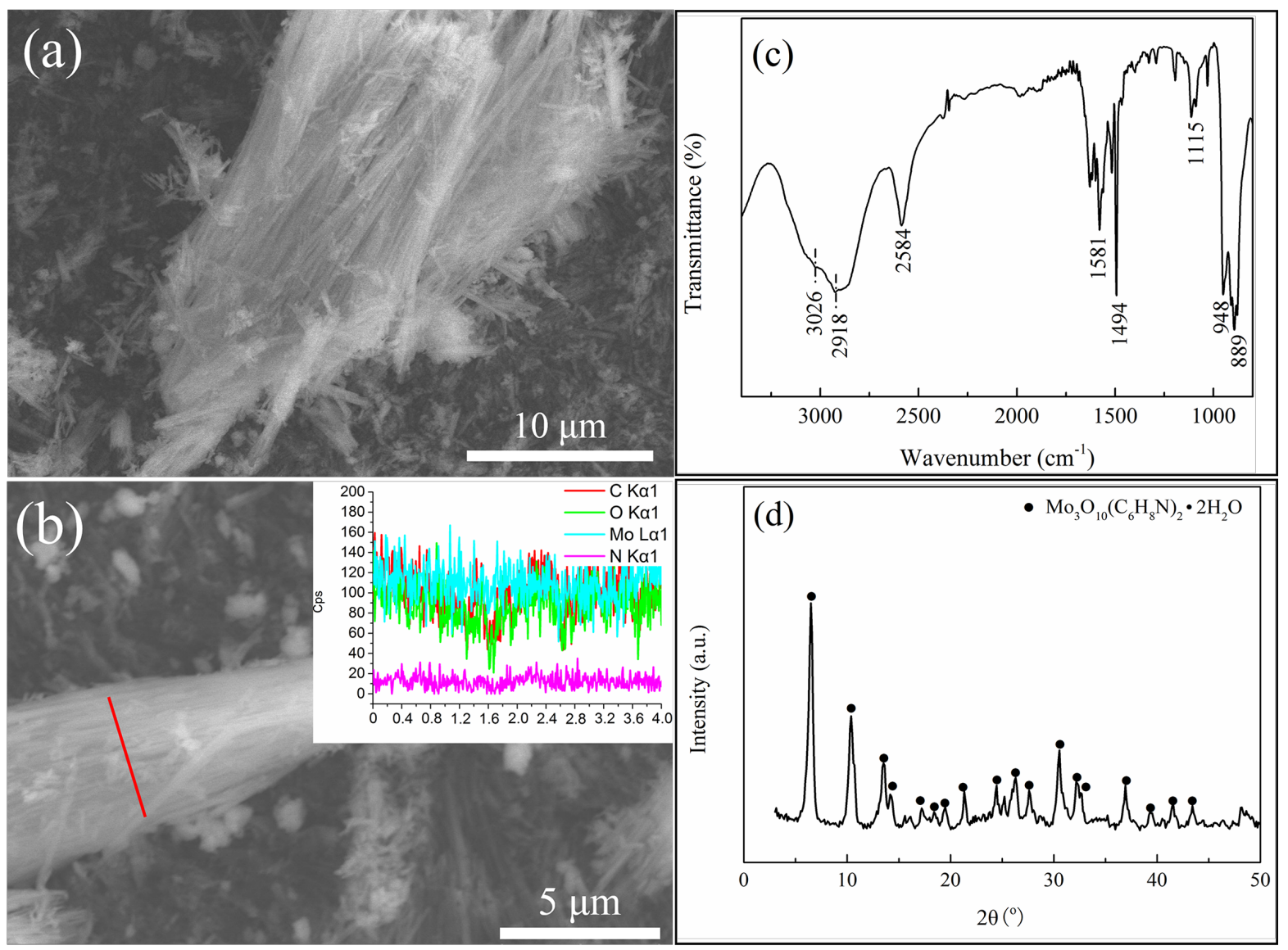


Figure 2

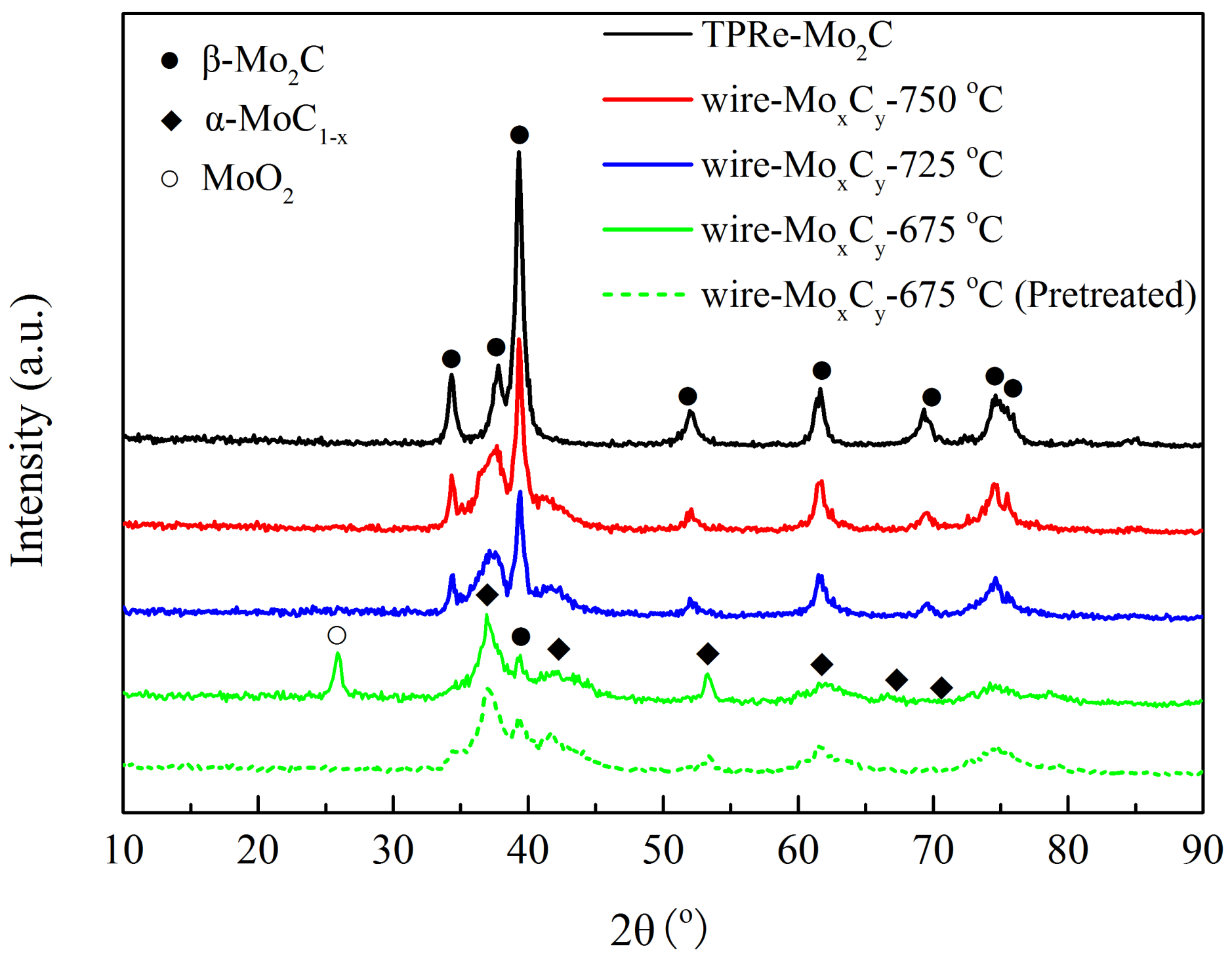




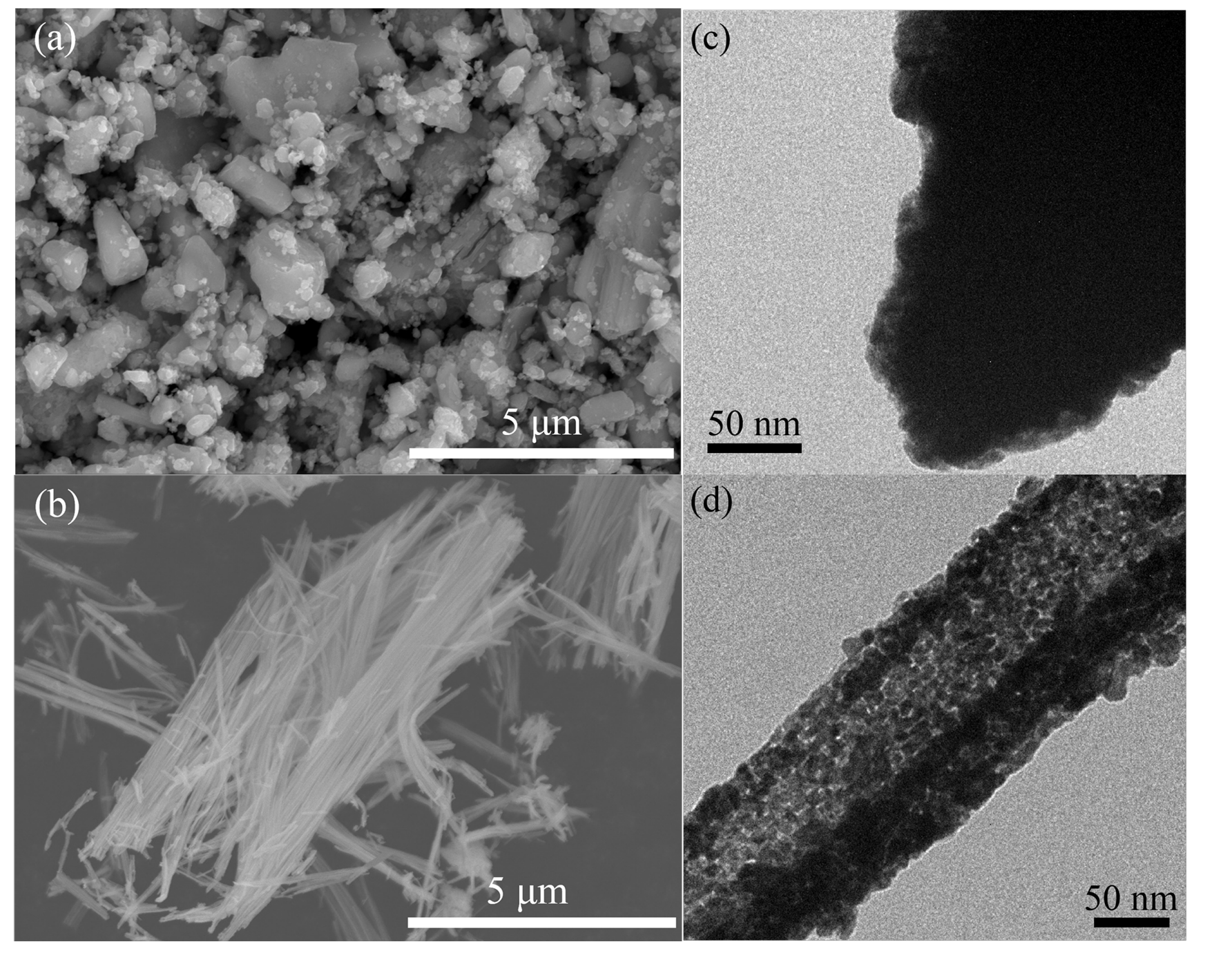

\section{Figure 3}


Figure 4

\section{Polymerization}
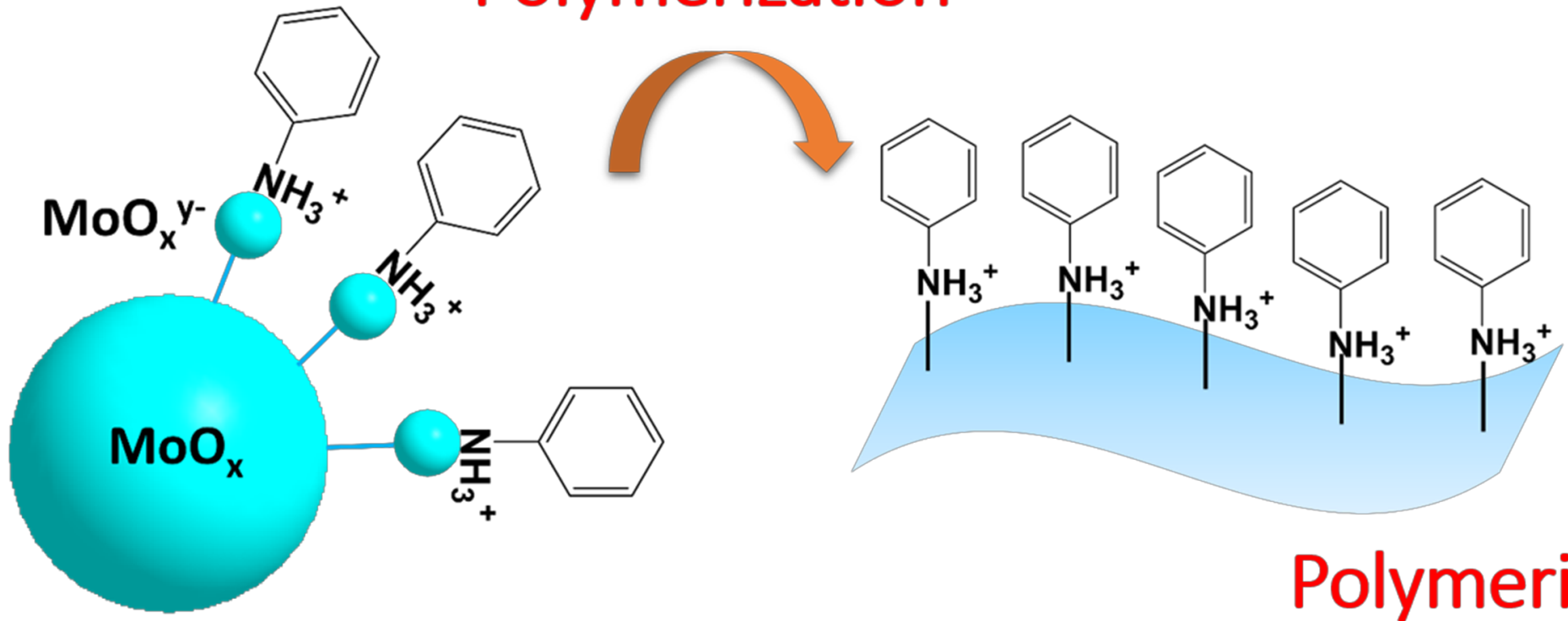

Polymerization

- $: \mathrm{Oo}_{x} \mathrm{C}_{y}$
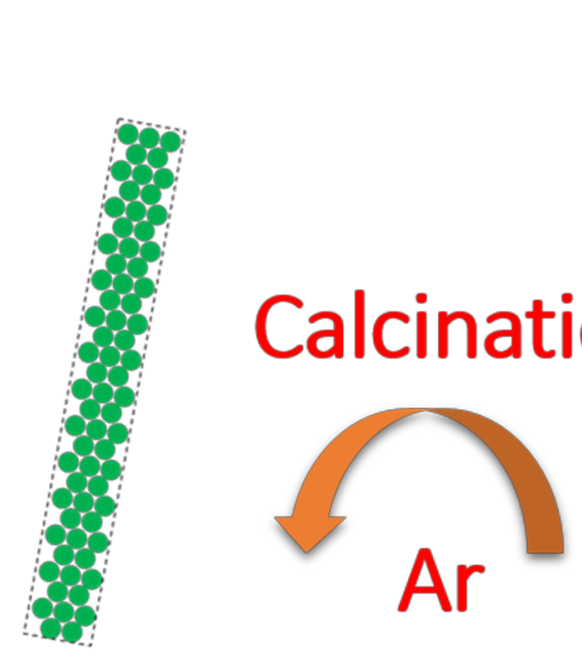

$M o_{x} C_{y}$ nanowires

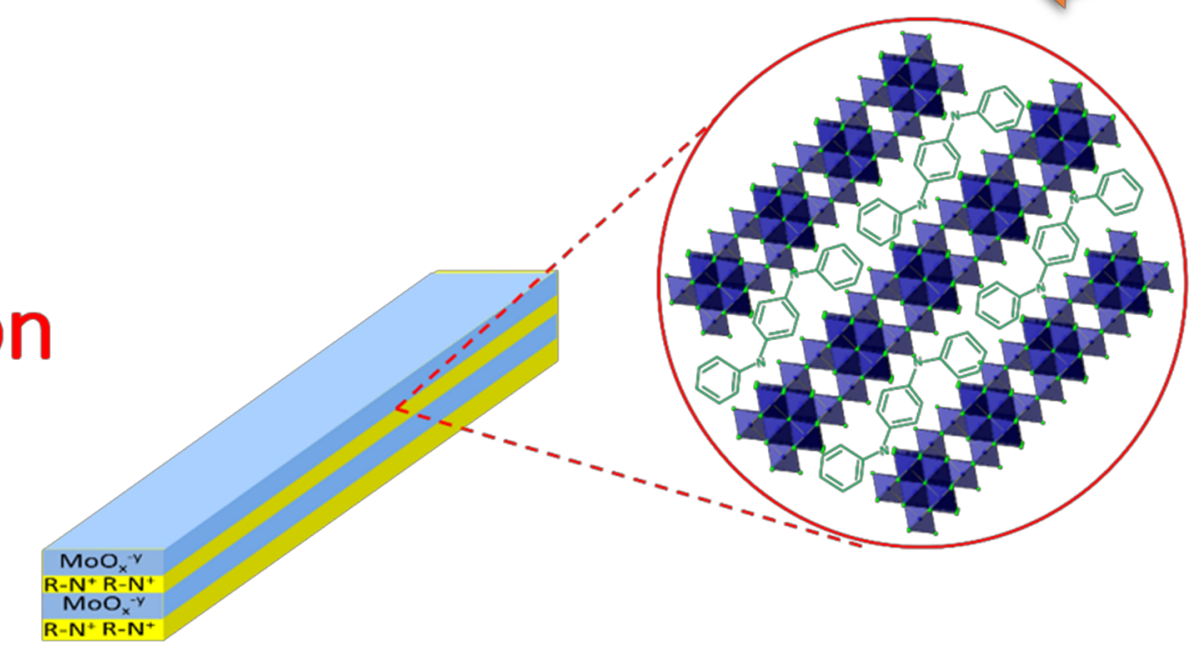

$\mathrm{MoO}_{x} /$ amine nanowires 
Figure 5

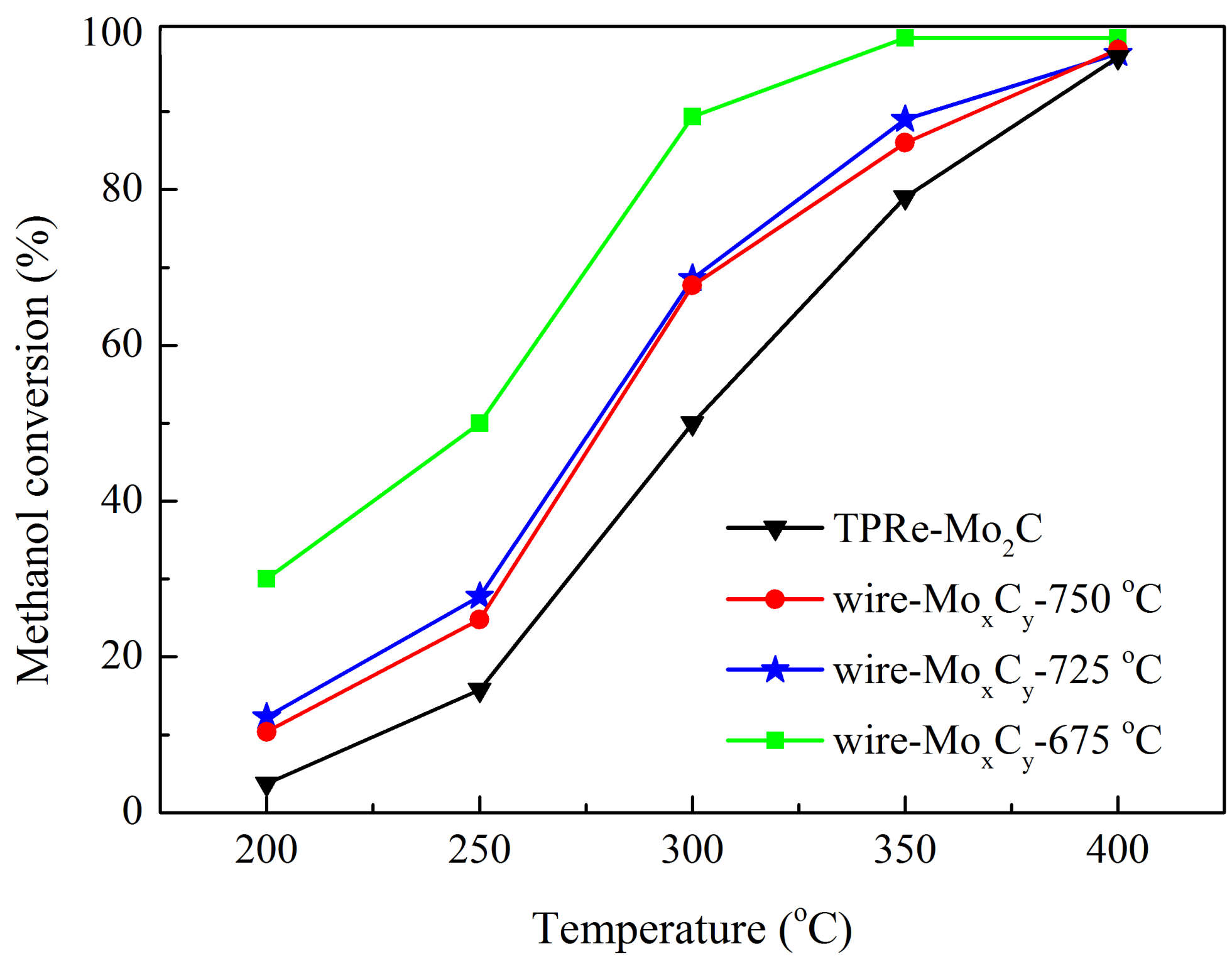



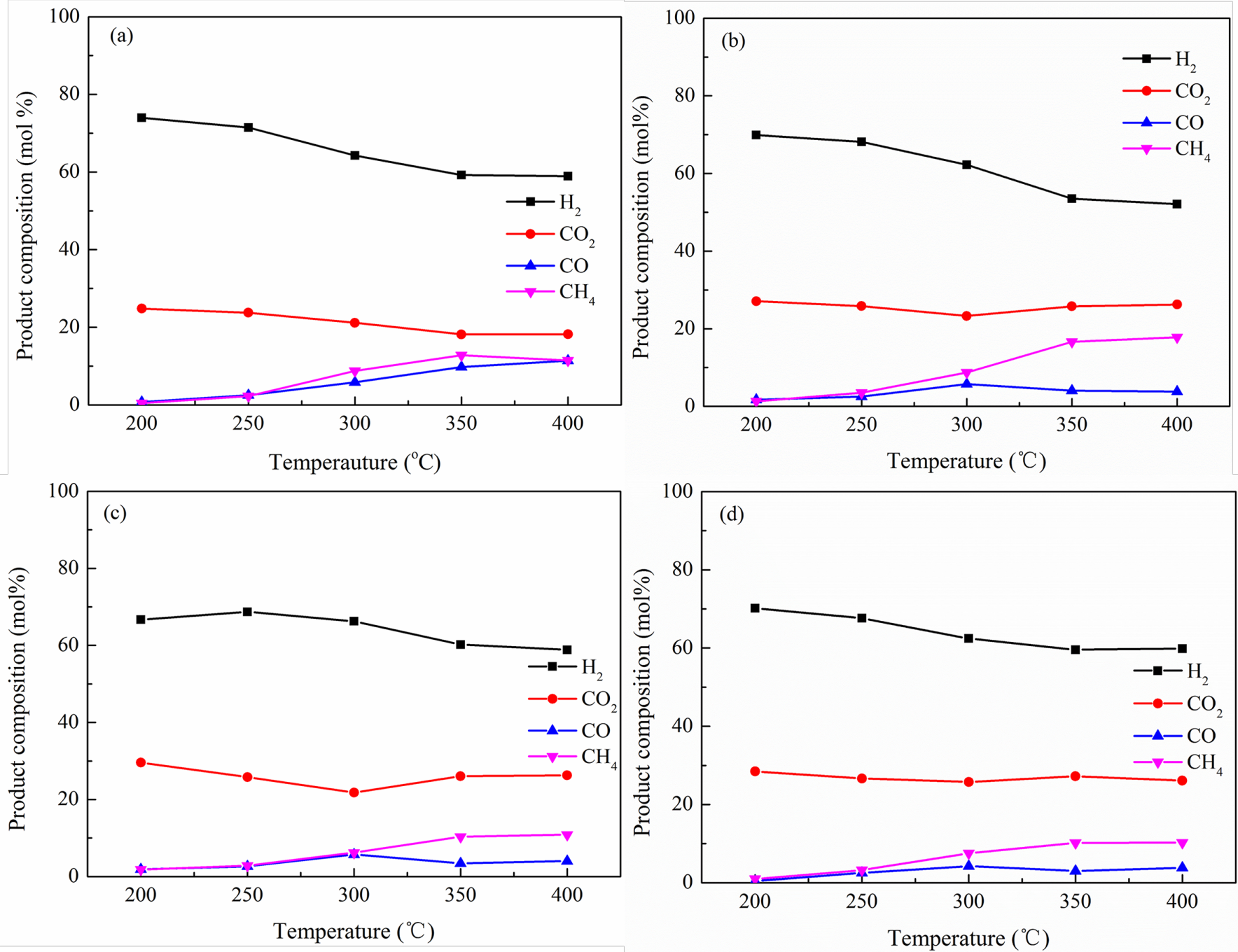
Figure 7

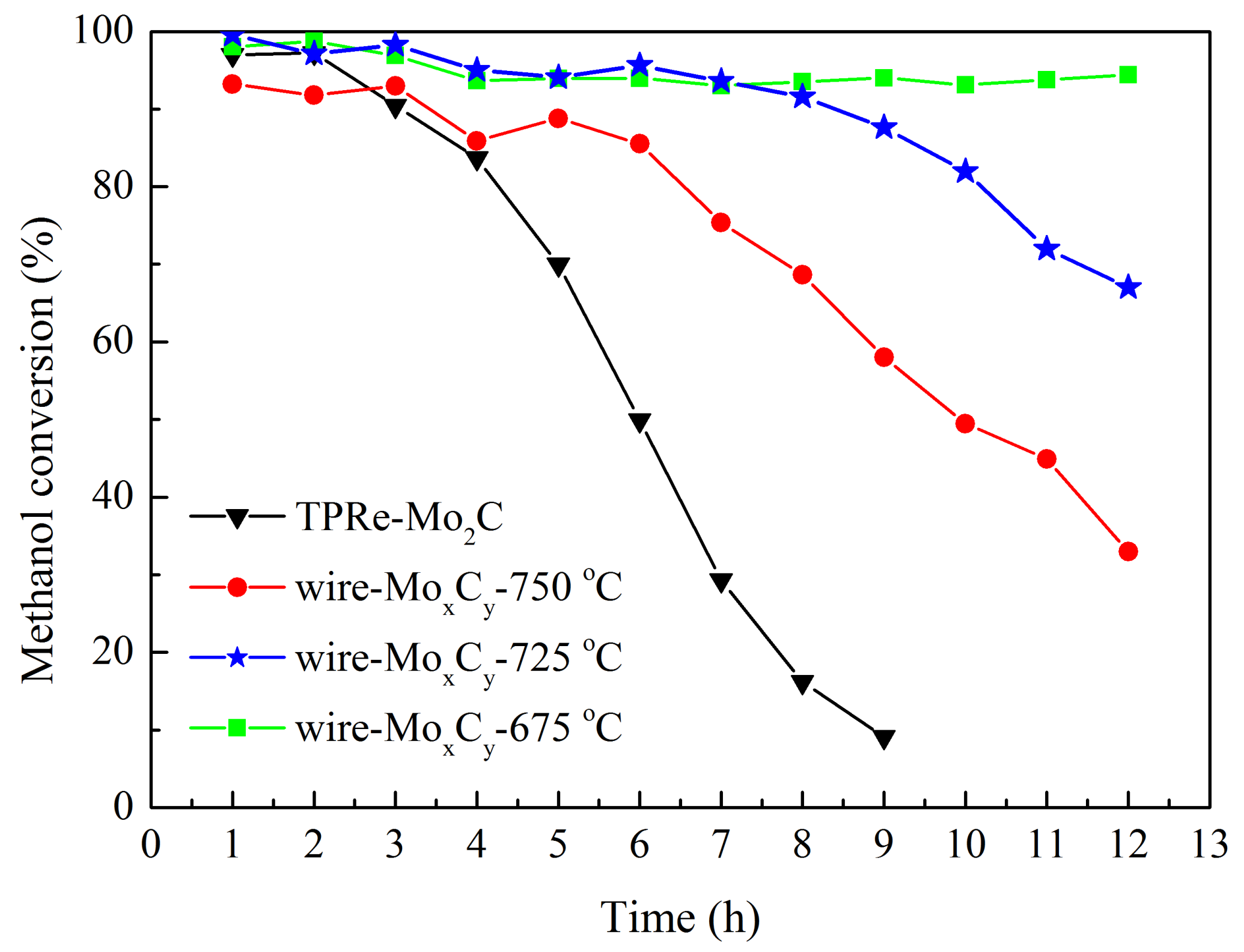


Figure 8
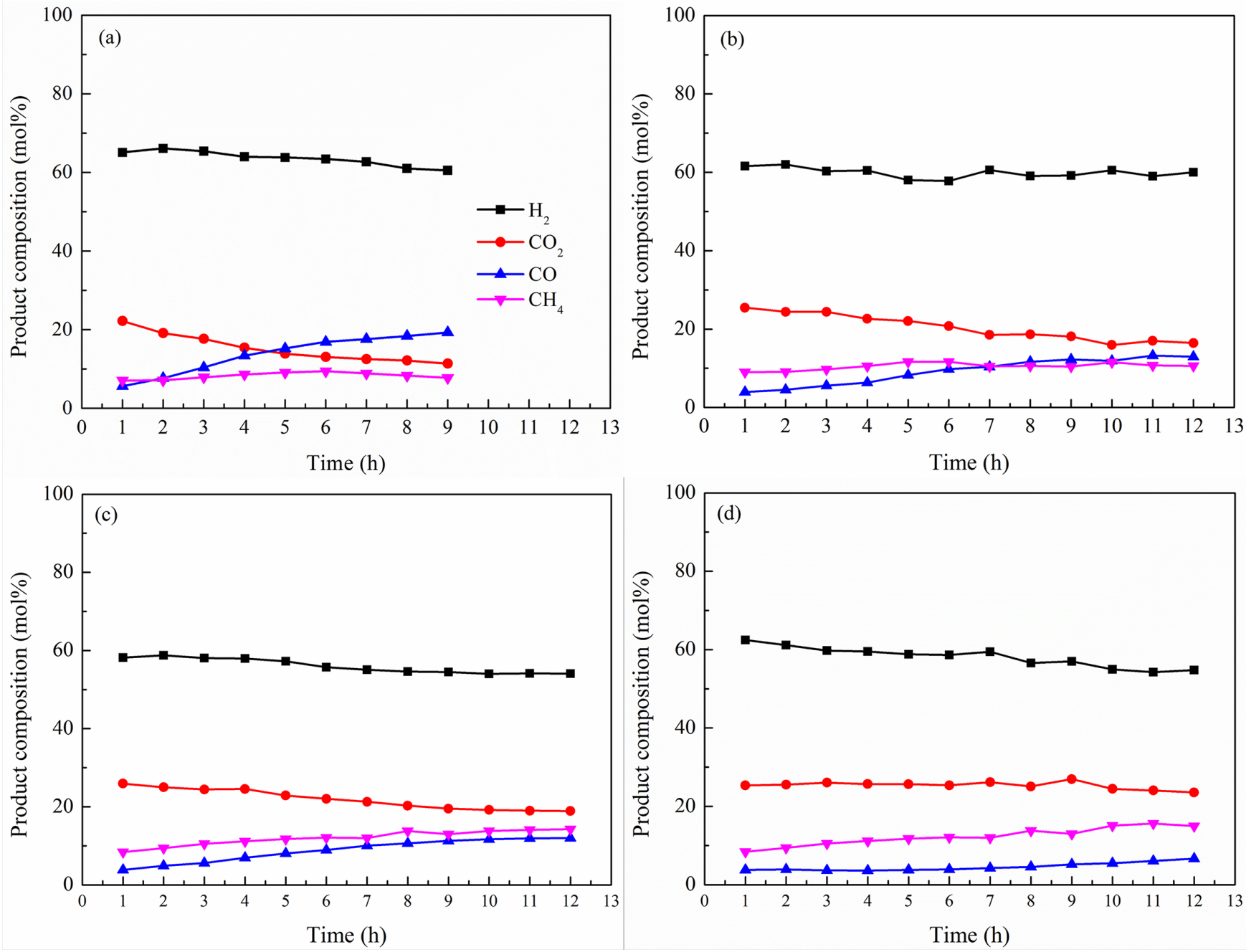
Figure 9

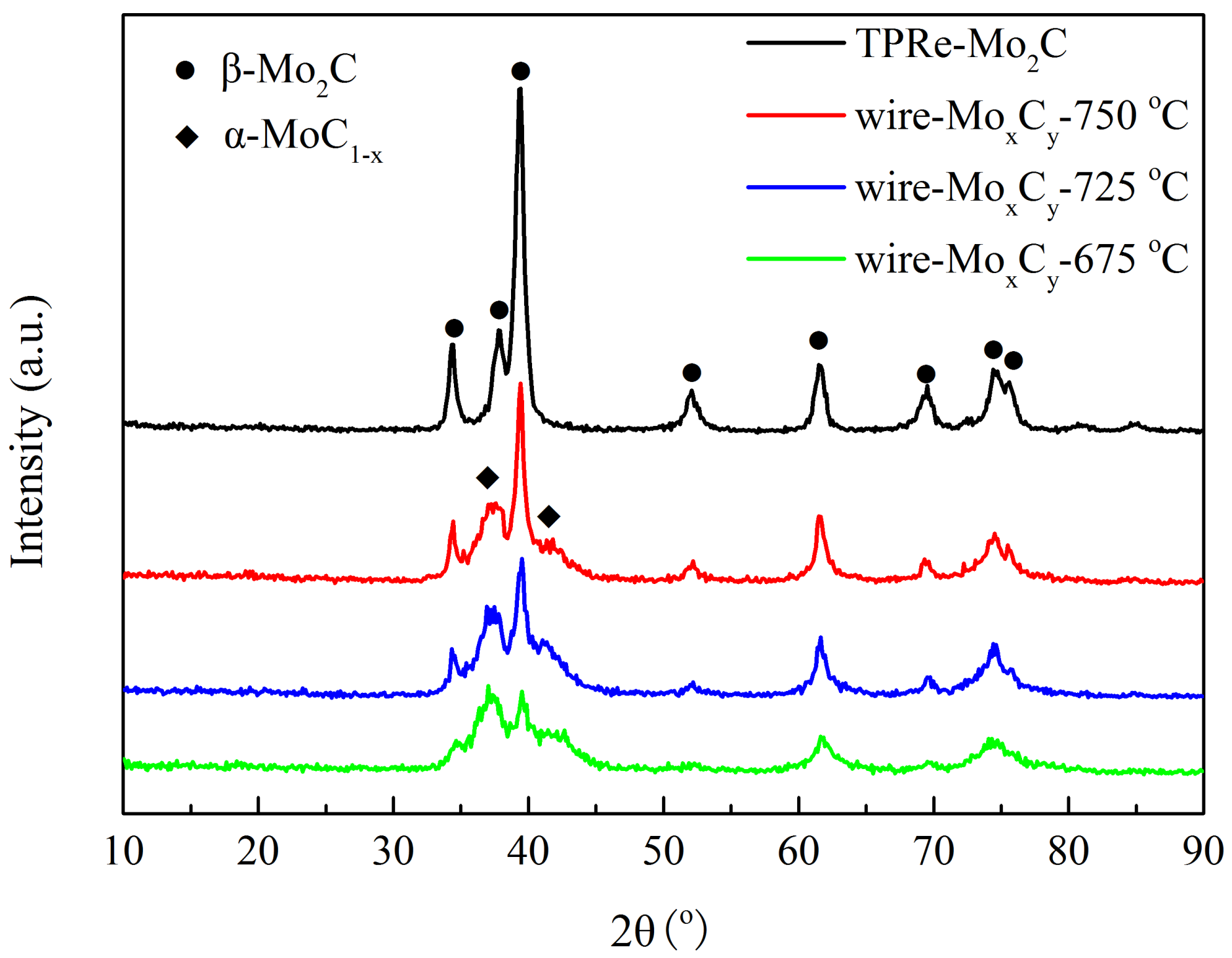


